\title{
Europe-topics in Europe's media
}

\section{The debate about the European public sphere: a meta-analysis of media content analyses}

\author{
Marcel Machill, Markus Beiler and Corinna Fischer
}

The existence of a European public sphere is disputed - not only in communication and media science. A common thesis in research is that a European public sphere can be constituted via the Europeanization of reporting in the national media. On the basis of a qualitatively oriented meta-analysis, this contribution aims to answer the question of whether such Europeanization is taking place in the European countries. With reference to 17 studies analysing media contents from several European countries, the empirical research carried out in German, English and French language since the beginning of the 1990s is systematically evaluated. All of the examined studies pursue an approach which compares European topics being reported in media in different European countries. The metaanalysis shows that in the 15 member states of the European Union prior to the enlargement of 2004 developmental tendencies of differing markedness up to a Europeanization of the national public spheres are discernible. Overall, EU topics account for an extremely small share of reporting in the particular national media. Players at EU level only feature in minor roles. It can be stated that the public spheres of the EU states continue to exhibit a strong national orientation. Keeping in mind that there has been only little empirical research in this field so far, the results of this analysis are a first step towards systematizing it - at a time when the debate about a European public sphere becomes even more important against the background of the ongoing growth and the discussions about the future of the EU.

\section{Introduction and presentation of the problem}

More than one third of the citizens of the European Union (EU) are of the opinion that the national media attach too little significance to EU topics. This is the conclusion drawn by the European Commission in its Eurobarometer survey ${ }^{1}$ (European Commission, 2004: 22). And yet there were enough opportunities to report on the ongoing political integration in Europe: the EU has just experienced the greatest enlargement in its history, mid-June 2004 342 million eligible voters elected a new European parliament. In addition, decisions were taken on a constitution for the political and economic community which political scientists

\footnotetext{
1 For the six-monthly Standard Eurobarometer survey the EU Commission has questions put to about 1000 citizens from all member states in connection with their opinions about, and attitudes towards, the EU (European Commission, 2004: 1).
} 
describe as a 'new protagonist in international relations' (Hrbek, 1998: 143) but which, at the same time, 'reveals elements which are normally attributed to states' (ibid.).

In the EU member states elections to the national parliament are normally big events which the media accompany weeks in advance with talk shows, special programmes and pages (Medien Tenor, 2002: 8). The media do not only assume the role of observers here: 'Today ... the impressions relevant to elections are mainly conveyed by media reporting' (Brettschneider, 2002: 37; for a detailed discussion Schulz, 1998). In the national media system television, radio, the print and Internet media make available as a matter of course information on parties and election programmes - after all, the politicians standing for election shall determine the fortunes of the country in the coming years.

Important political decisions at the level of the nation-state are therefore associated with the national public sphere. Public sphere in the sense of political public sphere is to be regarded as an intermediate system which mediates between society or its sub-systems and the political system or its core, the state administration' (Tobler, 2001: 8). Against the background of increasing European integration (Weidenfeld, 2001: $20 \mathrm{ff}$.) the issue of a European public sphere which fulfils similar functions assumes ever-greater significance (cf. also Hagen, 2004; Lünenborg, 2000: 391 ff.).

Two views of the European public sphere, presented in greater detail in the following section, are found in the current scientific discussion: one starts from an ideal image of a European public sphere that is independent of individual states whereas the other view lets it emerge as a result of a Europeanization of national publics (Gerhards, 1993: 100). Important in this connection is also the public deficit of the EU which is accompanied by a democracy deficit (cf. Trenz, 2002: 11; Kantner, 2003: 213). The public role of the media in modern and complex societies acquires special significance due to the fact that the citizens are essentially dependent on the information provided by the media (cf. Neidhardt, 1994: 10).

An analysis of media reporting as an essential indicator therefore recommends itself when attempting to answer empirically the question about the existence of a European public sphere. Content analysis permits statements about which topics occur, when, in which media, of which states, and how frequently. In this way it is possible to examine which information on EU politics is made available to the citizens of Europe via the media. The extent to which the recipients also use the information and the effect which it has cannot, of course, be answered solely by means of a content analysis (Merten, 1995: 29; Früh, 2001: 42). It is, however, possible to describe the source of information on the EU that is crucial for most of the citizens and therefore the basis of potential effects (cf. also Wiesner, 1990: $161 \mathrm{ff}$.$) .$

In order to be able to search extensively for signs of the existence or development of a European public sphere it would be desirable to conduct comparative analysis of media reporting in as many European states as possible over the longest period possible. How- 
ever, for reasons of research economics, it would be hardly possible to undertake such a research project. All of the content analyses of media reporting on the topic 'European public sphere' performed so far have also had to make a selection. Nevertheless, the available studies which consider comparatively partial aspects and periods of time as well as the media reporting of some states each provide a piece of the puzzle regarding the question of the European public sphere. The investigations that have already been performed can therefore be utilized in their totality if they are systematized and evaluated by means of a meta-analysis. This is the research approach pursued here.

Before explaining first the theoretical background and the methodological implementation of the analysis, it still remains necessary to clarify what is to be understood by 'Europe' when the expression European public sphere is used. In this contribution, 'Europe' is used synonymously with the term 'European Union'. The borders of the EU are identical to those of the EU of the 15 member states prior to enlargement in May 2004. This definition is determined by the currently available material: neither the theoretical literature relating to the field of research on the European public sphere nor the content-analysis studies which can be considered for the purpose of a second evaluation so far have included the ten accession states.

\section{Theoretical background}

\subsection{Europe, democracy and public}

The debate about the European public sphere is regarded as fundamental for the preservation or the realization of democracy in the merging Europe as, for example, Cathleen Kantner explains:

'The public deficit of the European Union is considered to lie at the heart of the European democracy deficit. Answering the question about the conditions for the constitution of a European public sphere is therefore essential for answering the question about the democratizability of European governance.' (Kantner, 2003: 213)

From the point of view of political science and jurisprudence, the existence of a democracy and legitimacy deficit in the EU is undisputed (e.g. Beetham and Lord, 1998; Majone, 1998; for an overview see Meyer, 2002: 39 f.). Briefly summarized, this deficit arises from the fact that the EU member states are handing over an increasing number of state responsibilities to institutions such as the European Council, the Council of Ministers or the Commission without democratic legitimization by the citizens of Europe of the decisions taken by those in authority. An example: many directives which the EU member states are subsequently obliged to transpose into national law are still proposed by the Commission and then passed by the Council of Ministers without these draft directives requiring the agreement of the EU parliament in which directly elected representatives of the people sit (Giering 2001: $116 \mathrm{ff}$.$) .$ 
Scientific consideration of the topic 'European public sphere' proves difficult: most common ideas of public sphere are based on the model of the nation-state (Imhof, 2003: 205 f.; Gerhards, 2000: 54). Although the European Union undeniably exhibits some characteristics of a state structure, it is, however, still considered to be a new type of protagonist and not a state (Hrbek, 1998: 143). And, of course, the peoples that live in the territory of the EU belong to different nations, nationalities and nation-states. It is therefore self-evident that the existing models of public sphere cannot apply here without being adapted to the conditions that obtain in the EU.

A further problem surfaces: since its foundation the EU as a political structure has found itself in a process of transformation, not only with regard to its inner constitutional order but also in terms of the continuous 'growth' through the addition of new member states. Whoever talks about any type of a European public sphere must in each case take into consideration the current status: is it still a question of the EU of the 12 as in 1993 when Jürgen Gerhards wrote his essay on 'West-European Integration and the difficulties with the emergence of a European public sphere' (emphasis by the authors)? Or is it the case of the EU now comprising 25 states? The very important aspect of the constantly changing EU territory should be considered when making statements about the European public sphere.

\subsection{Two models of a European public sphere}

In the theoretical debate about the existence of a European public sphere, two continuously recurring fundamental ideas are discernible (e.g. Gerhards, 1993: 100 ff.; van de Steeg 2000: 62 f.). Accordingly, a European public sphere is conceivable

1. as a pan-European public sphere independent of individual states or

2. as a European public sphere which emerges as a result of the Europeanization of the national public spheres.

Fundamentally it can be observed that the existence of a European public sphere (whatever its specific appearance) is rejected by the majority of the authors (e.g. Sievert, 1998: 18; Gerhards, 2000: $46 \mathrm{f}$.). In many cases there is even talk of a public deficit (cf. Baerns and Raupp, 2000: 39; Meyer, 2000: 107):

\footnotetext{
'A public deficit, that is to be distinguished from a democracy deficit, would exist when political decisions were taken increasingly frequently not by the nation-states but by the institutions of the EU while the reporting to the public remained bound to the nation-state and only considered to a small extent the European decisions and discussions of the decision-makers there: the consequence would be that the citizens would not be sufficiently informed about the decisions and discussions which nevertheless directly affect them.' (Gerhards, 2002: 141)
}

As shall be seen in the following, the model of the pan-European public sphere that is independent of the individual states requires different conditions than the model of the Europeanization of the national public spheres. Nonetheless it is also the more ambitious, the one that is more difficult to achieve and yet the 'more ideal' (Gerhards, 1993: 100). 


\subsubsection{A pan-European public sphere}

The prevailing view in communication research is that a pan-European public sphere independent of individual states does not exist (e.g. Gerhards, 2002: 142). Occasionally described as a 'utopia' (van de Steeg, 2003: 171), it is also regarded as relatively improbable that there will be a development towards it in the medium term (Gerhards, 2002: 142).

The most important precondition here is the existence of a common language in which the EU citizens can communicate with one another (Grimm, 1995: 42; Kielmansegg, 1996: 55; Kantner, 2002: 98 ff.). Such a language is, however, missing:

'Europe is not a communication community because Europe is a multi-language continent - the most banal fact is at the same time the most elementary. The peoples of Europe live in their languages as special 'structures of perception and understanding' and they will continue to live in them if Europe remains Europe.' (Kielmansegg, 1994: 27 f.)

Although English is the most widespread language in the EU states, as EU citizens indicated in December 2000 during the Eurobarometer survey (European Commission, 2001: 1), English cannot be regarded as the language of the masses and is by no means the lingua franca for the entire EU area.

The language aspect is to be seen in connection with the second precondition for a panEuropean public sphere that is independent of individual states: the existence of mass media (or other public forums) with EU-wide reach (Ruß-Mohl, 2000: 130 f.; Kantner, 2002: 95 ff.; Díez Medrano, 2003: 193). The assumption: since there is no language which all Europeans have command of to the same extent, there also cannot be any Europe-wide mass media via which the citizens of the various states can communicate with each other. There only exist a few media, each with a low readership or audience, which have a panEuropean approach or are distributed, at least in part, with largely identical content in different EU states, such as the Financial Times, the Economist, the European Voice (Kevin and Schlesinger, 2000) or, in the case of the audiovisual media, the TV news station Euronews (Machill, 1998: 434 ff.). Experiments for a European 'Television without Frontiers' (Meckel, 1994) such as Eurikon and Europa TV which were intended to promote the integration process in Europe (cf. Kleinsteuber and Rossmann, 1994; Siebenhaar, 1994) failed in particular because of the language aspect (cf. Beiler, 2000: 14).

Closely associated with the lack of EU-wide media, the lack of a uniform journalistic and media culture in the EU states is often cited (Sievert, 1998: $78 \mathrm{ff}$.; cf. also Wiesner, 1990). It comprises the self-image of journalists, how journalists are judged by others, the organization of journalistic work, the scientific discourse on journalism, the training of journalists, the comparison of journalistic products as well as basic social and legal conditions (Machill, 1997: 13 ff.). To these are added different historically formed ethical standards to which journalists submit themselves or their understanding of their role (Sievert, 1998: 88 ff.). All of this produces a situation in which a German journalist may understand the term 'news item' differently from a Spanish or British journalist (Machill, 1998: 432 ff.). 
To summarize: since neither a uniform European language nor Europe-wide media exist, the most important preconditions for the existence of a pan-European public sphere are absent. Consequently, the model of a European public sphere that emerges as a result of a Europeanization of the national publics shall now be presented.

\subsubsection{European public sphere as a result of the Europeanization of national publics}

A European public sphere which emerges as a result of the publics of the EU member states being Europeanized is considered a possibility by some authors (Kantner, 2002: 121; Gerhards, 2002: 142 ff.; cf. Hasebrink, 1995). EU media policy also needs to be mentioned in this connection (Meckel, 1994; Siebenhaar, 1994; see also Venturelli, 1993): the quota rule in the so-called Television Directive (Council of the European Communities, $1989,1997)$ can be interpreted as an attempt to produce a certain Europeanization of the national television stations by means of European media regulation. Accordingly, broadcasters shall 'reserve for European works ... a majority proportion of their transmission time' (Art. 4 Sect. 1). ${ }^{2}$

According to Gerhards, Europeanization would take place precisely when 'in the national public spheres, over time, reporting increasingly focused on the European decisions and the elites taking the decision' (2002: 142). In Gerhards's view, primarily an increase in the reporting of European topics in the national media is observable under Europeanization. Four indicators, which are linked in terms of content, are frequently cited for the more precise determination of the term Europeanization. They are presented in the following in slightly simplified form:

1st indicator: Protagonists in one place in the EU enter into debate with protagonists in other places (Díez Medrano, 2003: 19333; van de Steeg, 2003: 178). Koopmans and Erbe (2003: 6) also call this horizontal Europeanization. The term describes communicative connections between protagonists of various EU member states via the national mass media. In this description the EU is not only understood as a European central government. Instead, account is taken of the fact that the governments of the EU member states must look to the neighbouring states with regard to many of their decisions in order that a compromise is finally reached in Brussels.

2nd indicator: Protagonists in different EU states participate in debates on the same topics and agree with regard to the delineation of the problem (Díez Medrano, 2003: 193; van de

\footnotetext{
Inter alia, news programmes, which can be expected to have most influence on the public, are, however, exempt from the quota rule.

3 Díez Medrano (2003) derives his argumentation relating to the indicators for a pan-European public sphere from Weber (1983) and Anderson (1983) who concern themselves with the conditions for the emergence of nations or national sentiment. His concept of public sphere is closely linked to the question of how strong the feeling of solidarity is among the Europeans or rather how marked the European identity is (cf. also Kantner, 2002: 85 ff.; Wiesner, 1990: 168 ff.).
} 
Steeg, 2003: 178). This indicator is based on the previous one. It is directed towards the fact that a topic is discussed simultaneously in the media of several EU states. These debates strongly resemble each other. In an ideal scenario, the reporting in various EU states on topics with Europe-wide significance even takes place synchronologically (Sievert, 1998: 66 ff.; Grundmann et al., 2000: 300 f.).

3rd indicator: Protagonists from EU states enter into debate with protagonists at the EU level. Koopmans and Erbe (2003: 6) call this vertical Europeanization. It is encountered when there are communicative links between the national and the European level which are reflected in the respective national reporting.

4th indicator: Protagonists debate uniform aims and the same means from the perspective of the entire EU area (Díez Medrano, 2003: 193).

At first glance the empirical examination of these indicators appears to be more difficult than in the case of the first-mentioned image of a pan-European public sphere. In this case it is obviously necessary to analyse the debates between the protagonists more precisely. Since communication at the level of the political public that is under examination here takes place in the main via the mass media (Brettschneider, 2002: 37), these debates can be followed and analysed on the basis of the contents of national media. Accordingly, the intensification or the change in the reporting seems to be the subject of analysis which permits a statement to be made about a possible Europeanization of the national public spheres and therefore enables the emergence of this type of European public sphere.

In all theoretical approaches to Europeanization, one extremely important question remains unanswered: from which point is national reporting so europeanized that a new form of European public sphere is present which (in contrast to the model of the pan-European public that is independent of individual states) gets by without a common language and common media? The approaches from current theoretical research that are brought together here do not provide any measure for the point from which a national public sphere can be regarded as 'completely europeanized'. Consequently, in the case of the existence of one or more of the indicators, it is at best only possible to talk about Europeanization tendencies. However, it must be emphasized here that, corresponding to the four abovementioned indicators, different types or also dimensions of Europeanization are conceivable.

\subsection{Aim}

In summary: this contribution shall attempt to search for signs of the existence or development of a European public. The search takes place on the basis of the idea that a European public sphere can develop via the Europeanization of national public spheres which are in turn essentially constituted via the national media. In this regard, national differences in the reporting of the media in the various EU states are likely. First there shall therefore 
be examination of the intensity of the reporting of the national media a) via EU-related topics (Europeanization through synchronization), b) via actions and statements from EU protagonists (vertical Europeanization) and c) via other EU states (horizontal Europeanization) and second an investigation of how it has developed over time. Third it shall be asked whether the reporting on the EU in the national media intensifies at certain EU-specific events such as, for example, the introduction of the Euro and whether therefore a higher degree of Europeanization of the national public spheres is present. The central importance in journalism of reporting that is oriented towards events results from the assumptions of the news value theory (e.g. Schulz, 1990; Staab, 1990; Galtung and Ruge, 1965). The methodological design by means of which these questions are to be answered is presented in the following.

\section{Research design}

\subsection{Meta-analytical method}

The question of the existence and the development of a European public sphere shall be examined using a meta-analytical approach since, for pragmatic research reasons, it is not possible to perform one's own extensive content analysis that includes all EU states, compares many media with each other and encompasses a fairly long period of time (cf. with regard to the research strategies of internationally comparative studies Wirth and Kolb, 2003). However, meta-analysis enables a large part of the existing media content analyses on this topic to be summarized systematically and analysed with regard to the research question.

A meta-analytical research strategy is hardly applied in communication and media science. In the related disciplines, too, (e.g. Hunter and Frank, 1990; Glass et al., 1981) metaanalyses frequently only relate to the comparative evaluation of almost completely identical investigations, e.g. the results of extremely similarly designed experiments. A rough definition of meta-analysis is provided by Kiecolt and Nathan:

\footnotetext{
'Meta-analysis integrates the findings from a universe (or sample) of investigations of some phenomenon. That is, the study itself becomes the unit of analysis. ... Meta-analysis has been used primarily to evaluate experimental research in psychology and education, but the technique may also be applied to research in other disciplines' (1985: 10).
}

In the present case the challenge of the meta-analytical procedure lies in particular in making the different approaches of the included studies accessible to the question at issue. The quality criteria of scientific research, namely a systematic procedure and intersubjective comprehensibility (cf. Brosius and Koschel, 2003), must, of course, be observed. For the purpose of the comparison of various studies, an analysis framework in the form of a 
research-oriented question catalogue was developed (cf. 2.3.). ${ }^{4}$ The research tools primarily aim to present the results of the studies so that their contents can be interpreted. The results found in the studies were compared systematically, keeping in mind the different research designs. The procedure in this meta-analysis is therefore qualitative in nature.

\subsection{Selection of the studies for analysis}

The subject of this meta-analysis are 17 existing studies on media contents which, in the widest sense, concern themselves with the phenomenon of the European public sphere. The results of these studies constitute a comprehensive data basis for the meta-analysis. However, pragmatic research conditions imposed limits on the selection of the studies. Limiting factors were the languages known by the authors and the searchability of the studies. The selection criteria that resulted in the 17 studies in total were as follows:

- The study must be comparative, i.e. the media of at least two EU states must have been analysed.

- A content analysis of media reporting must have been performed in the study.

- The study must have been published after $1990^{5}$ because intensive research in the area of the European public sphere has been conducted since about this time. ${ }^{6}$ Studies published up to the end of November 2003 as the meta-analysis started were included. ${ }^{7}$

- The subject of the studies must be the political reporting of the media since this corresponds to the understanding of public sphere as a political public sphere which forms the basis of the current study (cf. 2.1).

- In addition, the study must concern the European public sphere directly or the EU itself (for example, in the form of its policy or institutions) or a topic field must have been investigated which is important throughout the EU or for the public of several EU states. ${ }^{8}$

4 In addition, a methodological comparison of the previous research approaches was performed in order to learn lessons for future comparative studies on the European public sphere. However, this cannot be presented here.

5 'Published' means that the study appeared in a scientific journal or an anthology, was published as a monography or is a dissertation. Academic theses could not be considered because, on the one hand, they cannot be reliably investigated and, on the other hand, inclusion of all searchable theses would have exceeded the framework of the present study.

6 The period prior to 1990 is partially covered because some of the studies selected for analysis also investigated it (e.g. Díez Medrano, 2001).

7 For this reason it was not possible to include, for example, the comparative study by Göler and Stammer (2004) on the media reporting of the European elections in Germany and France.

8 This criterion is difficult to understand since, without an analysis of its own it is hardly possible to describe how much reporting is necessary for a topic to be 'of importance' in the EU states. However, no borderline cases emerged during the practical selection of the studies. Only studies concerned exclusively with bilateral relations between states (for example, German-French summits) are clearly excluded by this criterion - provided that they do not have a connection to the EU. Consequently, this 'soft' description of the criterion for the selection of topics is considered sufficient for pragmatic research purposes. 
- The study must be in a language which the authors master (German, English, French). ${ }^{9}$

Furthermore, due to research-pragmatic reasons only studies could be selected, which were at all searchable, because they were quoted in the relevant literature or listed in electronic databases. ${ }^{10}$ In addition publication texts of the studies had to be available. ${ }^{11}$ Considering these criteria, a broad data basis for the meta-analysis was created by including the 17 most significant studies in this field.

Some of the studies were available in different versions, i.e. in different languages and scope. Use was always made here of the most detailed presentation, with preference given to German or English texts. In the following the most important key data of the investigated studies are first summarized to provide an overview of the analysis material.

\subsection{Overview of the material for analysis}

Eight of the 17 studies included in the meta-analysis were in the English language, eight were in German and one was in French. Germany and the UK are the most frequent states of origin of the investigated media (cf. Table 1 in the following). In 15 of the 17 studies German media are the subject of the analysis, British media accounting for 14 . Nine studies concern themselves with French media. Media from all of the other EU states are analysed much more rarely. In each case, the other countries are only investigated in one to five studies. This imbalance between the 'big' and the 'small' states as well as the circumstance that the investigation of the studies started from Germany must be taken into account during the interpretation of the content-related results (cf. section 4; see also note 9). Since considerably more data are available in connection with Germany, the UK and France, it appears possible to make more reliable statements about them than about the other states. The striven for comparison between the countries is also made more difficult.

On average, the content analyses examine media from four states. Only one analysis (Díaz Nosty, 1997) concerned itself with media from all 15 states, the analysis by Kevin (2003) included media from eight states, all of the others considered only a few states.

The studies also differ in terms of the types of media that are included. Nine of the 17 studies examine exclusively print media. Daily newspapers are investigated in eleven studies, weeklies or news magazines in five. Television reporting is the exclusive subject of analysis in five studies. Both types of media are considered in three studies. It is striking

9 This pragmatic and centrist restriction with regard to the 'biggest' languages can, however, cause the result of the meta-analysis to be distorted in a particular direction. Account is taken of this in the presentation and interpretation. However, on the basis of a cursory search for studies in other languages it can be assumed that this bias is not all too great.

10 For example, national bibliographies, European Commission Library Catalogue (ECLAS), subito, Karlsruher Virtueller Katalog (KVK).

11 For these reasons some studies could not be analysed, e.g. the study 'Euromedia' conducted by the European Commission between January 1995 and September 1997 (European Commision, 1995-7) as well as the study by Peter (2003). 
that there is no analysis of radio news or online media. The interpretation of the results of the meta-analysis must also take account of the differing composition of the media sample. For example, it is known from agenda-setting research (for an overview see Schenk, 2002: $399 \mathrm{ff}$.) that a different function with regard to the public is ascribed to different types of media. It is therefore to be assumed that print media tend to set the longer-term agenda whereas television has a spotlight function (cf. Eichhorn, 1996: 38 f.).

Table 1: Overview of the studies as well as the media analysed there and their EUstates of origin (in alphabetical order)

\begin{tabular}{|c|c|c|c|c|c|c|c|c|c|c|c|c|c|c|c|c|c|c|}
\hline \multirow[b]{2}{*}{ Studies } & \multicolumn{16}{|c|}{ EU-states of origin of the analysed media } & \multicolumn{2}{|c|}{$\begin{array}{c}\text { Analysed } \\
\text { media }\end{array}$} \\
\hline & A & B & $\mathbf{D}$ & DK & $E$ & $\mathbf{F}$ & FIN & GB & GR & 1 & IRL & $\mathrm{L}$ & $\mathrm{NL}$ & $\mathbf{P}$ & $\mathbf{s}$ & $\Sigma$ & $\Sigma$ & Type $^{1}$ \\
\hline Bange (1999a) & & & 口 & & & 口 & & $\mathbf{\square}$ & & & & & & & & 3 & 3 & Print \\
\hline Bange (1999b) & & & $\square$ & & & $\mathbf{\square}$ & & $\mathbf{\square}$ & & 口 & & & & & & 4 & 5 & Print \\
\hline Díaz Nosty (1997) & $\square$ & $\square$ & $\square$ & $\square$ & $\square$ & $\square$ & $\square$ & $\square$ & $\square$ & $\square$ & $\square$ & $\square$ & $\square$ & $\square$ & $\mathbf{\square}$ & 15 & 24 & Print \\
\hline Díez Medrano (2001) & & & $\square$ & & 口 & & & $\mathbf{\square}$ & & & & & & & & 3 & 7 & Print $^{2}$ \\
\hline Grundmann et al. (2000) & & & 口 & & & $\mathbf{a}$ & & $\mathbf{\square}$ & & & & & & & & 3 & 3 & Print \\
\hline Hackenbroch (2000) & & & $\mathbf{a}$ & & & & & $\mathbf{\square}$ & & & & & & & & 2 & 25 & Print $^{2} / T V$ \\
\hline Hodess (1998) & & & 口 & & & & & $\mathbf{\square}$ & & & & & & & & 2 & 8 & Print/TV \\
\hline Kevin (2003) & & & $\square$ & & $\square$ & $\square$ & & $\mathbf{\square}$ & & a & $\square$ & & $\mathbf{\square}$ & & $\mathbf{a}$ & 8 & 51 & Print $^{2} / T V$ \\
\hline Law et al. (2000) & & & $\square$ & & & $\square$ & & $\square$ & & & & & $\mathbf{\square}$ & & & 4 & 11 & Print \\
\hline Leroy and Siune (1994) & & a & & a & & & & & & & & & & & & 2 & 8 & TV \\
\hline Meckel (1994) & & & $\square$ & & & $\square$ & & $\mathbf{\square}$ & & & & & & & & 3 & 3 & TV \\
\hline Palmer (1998) & & $\mathbf{\square}$ & $\square$ & & & $\mathbf{\square}$ & & $\mathbf{\square}$ & & & & & & & & 4 & 19 & Print $^{2}$ \\
\hline Sievert (1998) & $\square$ & & $\square$ & & $\square$ & $\square$ & & & & & & & $\square$ & & & 5 & 8 & Print $^{3}$ \\
\hline Sturm and Bange (2000) & & & a & & & & & $\mathbf{\square}$ & & & & & & & & 2 & 8 & TV \\
\hline Trenz (2002) & & & $\square$ & & $\mathbf{\square}$ & & & & & & & & & & & 2 & 4 & Print \\
\hline de Vreese (2003) & & & & 口 & & & & $\mathbf{\square}$ & & & & & $\mathbf{\square}$ & & & 3 & 6 & TV \\
\hline de Vreese et al. (2001) & & & a & a & & & & $\mathbf{\square}$ & & & & & $\mathbf{\square}$ & & & 4 & 8 & TV \\
\hline$\Sigma$ & 2 & 3 & 15 & 4 & 5 & 9 & 1 & 14 & 1 & 3 & 2 & 1 & 6 & 1 & 2 & $M=$ & $M=$ & \\
\hline
\end{tabular}

Notes: 1 = if not indicated differently, in the case of print, only daily newspapers; $2=$ dailies and weeklies; $3=$ only weeklies

On average, almost 12 media per study are examined. However, considerable differences exist: the analysis performed by Kevin (2003), which incidentally includes both print media and television as well as the second highest number of states, provides a very large set of media. Three studies (Hackenbroch, 2000; Díaz Nosty, 1997; Palmer, 1998), each with about 20 analysed media, offer a medium set. The great majority of 13 out of the 17 studies include only relatively few media of about 10 or less.

It becomes apparent from a detailed look at the investigated media that the German Frankfurter Allgemeine Zeitung is analysed the most frequently (in 10 of the 17 studies). Second place is occupied by the British news programme $B B C 1$ News (in six studies). 
Analysis relatively frequently involves the German media Bild (5), ARD Tagesschau (5), Süddeutsche Zeitung (5), the British ITV News (5), The Guardian (5), The Times (4), the French Le Monde (5), Libération (4), Le Figaro (4) and the Spanish El País (4). There is an imbalance in the media represented in the studies: more often than other media newspapers are analysed which are distributed nationwide and have an elite readership. Overall, however, different media are considered.

The studies included in the meta-analysis comprise quite different periods of analysis and durations, ranging from very short investigations lasting only several days to long-term investigations (Díez Medrano, 2001). Nine studies, just over half, pursue an event-oriented approach. The most frequently investigated reporting event (in part, different events in one study) is the introduction of the Euro on 1 January 1999 (five studies). Four studies treat different European elections and three cases different sessions of the European Council. Further events are the Kosovo crisis (two studies) as well as the resignation of the Santer Commission and Joschka Fischer's Berlin speech of 12 May 2000 (one study each). The different analysis periods and the different events also mean that it is more difficult to make comparative statements about the European public sphere and its development over time.

The essential (formal) 'adjusting screws' for the range of internationally comparative studies are therefore the number of included states, the number and types of included media (and the extent of the analysis of the reporting of these media) as well as the period of the study. The more extensive these factors are, the greater the number of statements that can be made. As the scope increases so too, of course, does the research effort - this representing a problem for this field of research. After this overview of the material considered in the study, the results of the meta-analysis will now be presented.

\section{Results}

Since a qualitatively oriented meta-analytical research design is used here in order to be able to bring together 17 studies that differ greatly in terms of methods and content, it is obviously not possible to provide any absolute answers to the above-mentioned research questions relating to the degrees to which there is reporting on EU topics, EU protagonists and other EU states. It can only be a question here of establishing a relation between the result of the particular studies for the purpose of interpretation. In addition attention must be paid to the different definitions of an EU topic or an EU protagonist in each study. The analysis is performed on the basis of the publication texts of the examined studies. It therefore follows the weighting of the particular researchers with regard to the selection of the results of the analysis deemed worthy of publication. In the case of unclear references in the publication texts of the studies, in cases where there is no direct comparability of results from different studies or if the texts contradict the attached tables or graphics, in case of doubt, use of the results is dispensed with. 


\subsection{National differences in the reporting}

Clear differences in reporting by the media between the individual EU states are revealed in the meta-analysis. In the following they are first subdivided according to reporting on EU topics, EU protagonists and other EU states and then subsequently brought together again.

\subsubsection{Reporting on EU topics (Europeanization by synchronization)}

In the case of the topics associated with the EU clear differences in reporting become evident between the individual states. One special feature is apparent: as soon as a particularly large amount of reporting is devoted to one event in a state, the respective authors of the studies justify this with reference to national events or debates connected with the particular EU topic.

German media report more frequently on EU topics than do the media of many other EU states. Four studies agree on this finding. However, in two cases (Hackenbroch, 2000; Hodess, 1998) the more intensive reporting is justified by mentioning national German discussions on the particular topic. Extensive reporting on the EU is also provided by Finnish media. Although only investigated in the study by Díaz Nosty (1997), they are here compared with media from all the other EU states and over a comparatively long period of time.

In connection with Spanish media, too, only the results from Díaz Nosty (1997) are utilizable with regard to this question. Accordingly, in comparison with the media of other states, Spanish media report a great deal on EU topics. Again only on the basis of one study (de Vreese, 2003), the media in Denmark concern themselves quite frequently with EU topics. This applies both to reporting occasions linked to particular dates such as summits or the introduction of the Euro and routine weeks. However, in the case of this study attention must be paid to the fact that the evaluated periods of time are located at a relatively short distance from the EU referendum in Denmark in September 2000. The few possible statements about the French media indicate that although they report overall to a lesser extent than the German media, extremely intensive reporting occurs in connection with a special event (European elections 1999).

By comparison, the media in the Netherlands only report to a moderate extent on EU topics. However, the performance of the country in the study by de Vreese (2003) is justified by the fact that during the period of investigation a national event (government crisis) overshadowed the EU event (European elections), this resulting in a particularly small amount of reporting.

Examination of the studies on British media reveals that the UK represents a special case with regard to EU topics. Although five of the studies agree that the country's media report extremely little on EU topics, this changes when the focus is on currency-policy topics. British media report much more intensively on this subject than on other EU topics. In the UK this topic is also more frequently presented as a political issue - in other states it is at 
most 'only' a clearly economic matter. British media also report to an unusually large extent on the Kosovo crisis.

With regard to Italy and Belgium it can be stated only on the basis of one study each (Kevin, 2003; Palmer, 1998) that there is very little reporting on EU topics in these countries. In the studies examined for the purpose of the meta-analysis, no detailed statements regarding EU topics can be derived for Austria, Greece, Ireland, Portugal and Sweden.

\subsubsection{Reporting on EU protagonists (vertical Europeanization)}

Overall the media in the individual examined states name protagonists from home much more frequently than players on the EU stage (e.g. the European Commission, associations at the EU level or individual members of the European Parliament). This is true of both particular EU-specific reporting occasions such as, for example, the introduction of the Euro or European summits and during 'routine periods'. Only Trenz (2000) arrives at a different result in his analysis of the reporting on the resignation of the Santer Commission: according to him, the reporting on this topic in Spain and Germany was associated more with the EU than with national protagonists.

The examined studies show that the media of the Netherlands report unusually frequently on EU protagonists. This finding applies both to directly EU-related reporting and to Netherlands reporting as a whole. The frequency with which EU protagonists are named is therefore not linked to EU-specific topics but is particularly marked in the case of EU topics.

Although the UK media report more frequently than those of most other states on EU protagonists, one special feature is discernible in the studies: reporting in British media appears to be particularly closely associated with EU protagonists when currency-policy issues such as EMU or the introduction of the Euro are discussed. Players at the EU level are named in the Danish media at a similarly high frequency to that found in the British media. However, this finding can only be supported with reference to one study (de Vreese, 2003).

In German and French media EU protagonists are named less frequently than in the media of the above-mentioned countries. Austria's media also report less frequently on the players at EU level than the frontrunner, the Netherlands. However, this can also only be supported by the results from one study (Sievert, 1998). This limitation likewise applies to the finding that Spanish media report less on EU protagonists than German media (Trenz, 2002).

On the basis of the studies examined in the meta-analysis, no detailed or clear statements with regard to EU protagonists can be derived for Belgium, Finland, Greece, Ireland, Luxembourg, Portugal and Sweden. 


\subsubsection{Reporting on other EU states (horizontal Europeanization)}

The analysed studies only rarely examine whether and how reporting on other EU states occurs in the individual EU states. Frequently the situation is viewed from the other side: the researchers check which states are named, and how frequently, in the total reporting of all the other states that are examined in each case. Consequently, this aspect shall be briefly discussed here.

Although only very few results can be found in the studies, the analysis performed by Kevin (2003) indicates that the media in Sweden report on other EU states more frequently than those in other countries. Austria, Germany, France and the Netherlands can be numbered among the states which make reference to foreign EU states moderately often. With regard to Spain, completely contradictory judgements arise from two studies (Kevin, 2003 and Sievert, 1998). British media report very little on other EU states as do the Irish and Italian media. No utilizable results can be found in the studies in relation to Belgium, Denmark, Finland, Greece, Luxembourg and Portugal.

It becomes clear from the meta-analysis that the most highly populated EU states, the UK, Germany and France, are themselves most frequently the subject of reporting in the other EU states or that reference is made to them in articles or contributions. Owing to contradictory results, it is not possible to reliably determine which of the three states is the most important in this regard for the reporting of the media from other states. References to Italy are also quite frequently made in the media of other EU states.

Results for Belgium are only found in one study (Díaz Nosty, 1997). They suggest that information about the EU does not originate from any other EU state so frequently as from Belgium. This finding is hardly surprising in view of the fact that many EU institutions are based in Brussels.

In the case of Denmark, Finland, Sweden, Portugal and Ireland, it can be stated on the basis of the study by Sievert (1998) that the media of other EU states do not make any reference to them at all. It is not possible to make reliable statements about Austria, Spain, Greece, Luxembourg and the Netherlands.

\subsubsection{Summarizing presentation and discussion}

The meta-analysis shows that the Europeanization of the national public spheres in the states of the EU has advanced to differing extents. Characteristics, which are compiled in the following, can be determined for the public spheres of the individual states. For the purpose of clarity, the attempt is made to represent visually in a table the tendency in EU reporting (cf. Table 2)

Overall, German media report a great deal on EU topics and make reference to other EU states moderately often. However, in comparison with some states, EU protagonists are only named with moderate frequency. Germany itself appears very frequently in the re- 
porting by the media of other states. Danish media also concern themselves quite frequently with EU topics. By contrast, Denmark practically never appears as the subject of reporting in other states. The media of the Netherlands report unusually frequently with reference to EU protagonists. This applies not only to the EU reporting but to reporting as a whole in the country. The media make references to other EU states moderately often.

Table 2: Comparative overview of the national differences in the Europeanization of media reporting (tendencies)

\begin{tabular}{|c|c|c|c|c|c|}
\hline \multirow[b]{2}{*}{$\begin{array}{l}\text { EU-states of origin of the } \\
\text { examined media }\end{array}$} & \multicolumn{3}{|c|}{$\begin{array}{l}\text { Intensity of the reporting in compari- } \\
\text { son with other EU states on }\end{array}$} & \multirow{2}{*}{$\begin{array}{l}\text { Overall tendency of the } \\
\text { degree of Europeaniza- } \\
\text { tion in comparison with } \\
\text { other EU states }\end{array}$} & \multirow{2}{*}{$\begin{array}{l}\text { Naming in } \\
\text { the media of } \\
\text { other EU } \\
\text { states }\end{array}$} \\
\hline & EU topics & $\begin{array}{l}\text { EU-pro- } \\
\text { tagonists }\end{array}$ & $\begin{array}{l}\text { other EU } \\
\text { states }\end{array}$ & & \\
\hline A - Austria & & 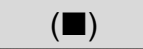 & $\mathbf{\square}$ & moderate & \\
\hline B - Belgium & $(\nabla)$ & & & low & $(\mathbf{A})$ \\
\hline D - Germany & $\Delta$ & $\square$ & $\square$ & high & $\Delta$ \\
\hline DK - Denmark & $(\mathbf{\Delta})$ & $\mathbf{\square}$ & & high & $(\nabla)$ \\
\hline E - Spain & $(\mathbf{\Delta})$ & $(\nabla)$ & & moderate & \\
\hline F-France & $\square$ & $\square$ & $\square$ & moderate & $\Delta$ \\
\hline FIN - Finland & $(\mathbf{\Delta})$ & & & high & $(\nabla)$ \\
\hline GB - Great Britain & $\nabla$ & $\mathbf{\square}$ & $(\nabla)$ & low (special case) & $\boldsymbol{\Delta}$ \\
\hline \multicolumn{6}{|l|}{ GR - Greece } \\
\hline I - Italy & $(\nabla)$ & & $(\nabla)$ & low & $\square$ \\
\hline IRL - Ireland & & & $(\nabla)$ & low & $(\nabla)$ \\
\hline \multicolumn{6}{|l|}{ L- Luxembourg } \\
\hline $\mathrm{NL}$ - Netherlands & $\square$ & $\Delta$ & $\square$ & high & \\
\hline $\mathrm{P}$ - Portugal & & & & & $(\nabla)$ \\
\hline S - Sweden & & & $(\mathbf{\Delta})$ & high & $(\nabla)$ \\
\hline
\end{tabular}

Notes: $\mathbf{\Delta}=$ high; $\boldsymbol{\square}=$ moderate; $\boldsymbol{\nabla}=$ low; $(\quad$ ) = assessment only on the basis of one study; empty cells = no statement possible

French media devote themselves with moderate frequency to EU topics and refer to EU protagonists and other EU states as frequently as in the media of other states. France itself is named unusually frequently in the media of other EU states. Compared with the reporting of other states, Austrian media refer moderately often to EU protagonists and foreign EU states. The media in Spain report to a relatively high degree on the topics associated with the EU but refer comparatively rarely to EU protagonists.

The UK media report more on EU protagonists than the media of other states, but only when currency-policy topics are involved. Overall, there is unusually little reporting on EU topics in this country although the situation is different with regard to currency-policy topics. In addition, when EU reporting occurs, the UK media place a political emphasis much more frequently than the media of other states in which the EU is mostly an economic topic. UK media refer comparatively rarely to other EU states. By contrast, the country plays a very 
important role in reporting in foreign EU states. Some of these findings on UK media may sound contradictory, but it should be considered that, for example, reporting on EU protagonists and on other EU member states in this contribution are seen as different research items. So the results cannot be generalised easily in every case.

Italian media report only rarely on EU topics and other EU states. By contrast, the media in foreign EU states refer relatively frequently to Italy. Belgian reporting also very rarely deals with EU topics. By contrast, Belgium plays an extremely important role as the country of origin for information on EU topics due to the fact that many EU institutions have their headquarters here. Very little reporting on other EU states is to be found in Irish media just as Ireland hardly features in articles and contributions in other EU states.

It is hardly possible to make definite statements about the reporting of Finnish media on the basis of the analysed material. The few available results indicate that there is a considerable amount of reporting on EU topics but that Finland itself does not play a significant role in the media of other states. Comparatively speaking, Swedish media report very frequently on other EU states. However, Sweden itself hardly figures in reporting by other states. On the basis of a very limited data base, a relatively high degree of Europeanization is to be assumed for these two states.

No definite statements can be made on the basis of the meta-analysis in connection with the European media public of Luxembourg, Greece and Portugal.

In summary, common features in the reporting of the media of various states are also discernible. For example, the meta-analysis shows that, in all states, EU reporting only accounts for a small part of total reporting. Furthermore, the media of all the states mostly focus on national protagonists when topics of EU-wide significance are involved. The results create the impression that national interests and debates often exert a very strong influence on the reporting related to EU topics. When the media of a country refer to other EU states attention focuses - along with Belgium as the 'capital of Europe' - particularly frequently on Germany, France, the UK and also relatively frequently on Italy. This is hardly surprising given that these are the politically and economically most powerful states in the EU. Consequently, the news factor 'elite nation' comes into play. Partially contradictory results are due to differences in the approaches pursued by the studies. There is still a great need for research, above all in relation to the smaller EU states.

It is therefore not possible at this point to arrive at an overall judgement about which national public sphere of the 15 examined EU states is the most or least europeanized even if it can be established as a rough tendency that German, Danish and Netherlands media devote themselves more to Europe. Not only Denmark but the other Scandinavian countries, too, appear to possess relatively europeanized media whereas in France, Spain and Austria the media tend to report moderately, in Italy, Ireland and Belgium to a low extent, on Europe. The UK represents a special case because in British media attention focuses especially on Europe's currency-policy issues with highly personalized reporting of the EU 
protagonists. By contrast, only a small amount of reporting is devoted to other EU topics and states. It would be more accurate to talk here of a 'negative Europeanization'.

In connection with the first research question it can therefore be stated in summary that the Europeanization of national public spheres in the EU has advanced to differing extents. The results of the meta-analysis suggest that debates on EU topics in different national public spheres often remain linked to national protagonists and interests.

\subsection{Development of EU reporting over time}

The meta-analysis is unable to find any indications that an increase in the degree of Europeanization of the national public spheres has taken place over time. This applies to the investigation of a period of time lasting several years and the pure set of reporting on EU topics, EU protagonists and EU states. Account must be taken here of the fact that the studies included in the meta-analysis only very rarely analyse such long periods of time and hardly ever explore the question of differences between individual EU states.

Primarily, such statements are only permitted by the studies by Díaz Nosty (1997) and Díez Medrano (2001). In particular with regard to the reporting of EU topics, both indicate constancy in the type and quantity of reporting. Even these studies do not provide any results in connection with EU protagonists and the thematization of other EU states.

In contrast to the two previously mentioned studies, Hodess (1998) comes to the conclusion during the comparison of the periods 1985 and 1990/1 that clearly more intensive EU reporting can be found during the later period. However, account must be taken of the fact that the author examined events occurring at particular points in time, namely EU summits. Consequently, a generalization in the sense of a conclusion that the quantity of reporting has increased during the period from 1985 to 1991 does not appear appropriate. However, since the type of events are comparable it is possible to speak of a certain increase in the sensitization of the media.

Both Hodess (1998) and Díaz Nosty (1997) establish an increase in commenting contributions in the media they examined. A more intensive commentary may indicate that journalists consider the EU to be more important than previously and that a topic is debated more controversially in the national public sphere than before, something which can be interpreted as a Europeanization tendency. However, the limited data base related to this aspect and the only very short investigated periods that are compared, amounting to only a few years, do not permit generalization or the determination of a clear tendency.

The second research question about whether the degree of the Europeanization of national public spheres has increased over time (operationalized as an increase in reporting on the $\mathrm{EU})$ can therefore not be answered on the basis of the meta-analysis of the present studies since the data base for such statements is too limited. 


\subsection{Importance of reporting events}

The studies examined in the analysis all come to the conclusion that EU reporting by the media in the various states increases very considerable at particular points in time. These points in time are closely associated with certain events. However, attention must be paid to the fact that many of the studies pursue an event-oriented approach anyway, i.e. they link their period of analysis to a particular EU event. For this reason they provide a great deal of information on the importance of reporting events. As a rule, the statements in the studies refer to the amount of EU reporting in general.

The analysis shows that the intensity of EU reporting always rapidly increases when a topic which is of interest EU-wide or at least in several EU states is connected with a particular event. It is possible to differentiate here between several types of events which each impact differently on reporting:

\section{Events connected with EU policy or the continued development of European inte-}

gration. Included here are, on the one hand, sessions of the European Council or European elections and, on the other, for example, the introduction of the Euro or the accession of new member states. Such events are examined in the studies preferentially. The analysis makes clear that a considerable increase in EU reporting occurs on the days of such events, sometimes even shortly before. However, it is clearly not the case that the particular EU topic then dominates the national news agenda. It is only visible at all. De Vreese summarizes this phenomenon as follows: 'News about the EU is cyclical: it enters the news agenda and vanishes immediately after the end of a specific event' (2003: 102). In a comparison with a routine period he establishes that the percentage of reporting on the EU summits in 1999 and 2000 is higher by a few percentage points. In addition, individual results (e.g. Trenz, 2002) indicate that EU events result in a synchronous increase in the quantity of reporting in the states that are examined in each case.

2. National events in individual EU member states. These can, on the one hand, themselves be occasions for reporting on EU topics. The investigated studies name, for example, the speech on fundamental principles in Europe by the German foreign minister Joschka Fischer at Berlin's Humboldt University in May 2000 (Hackenbroch, 2000). This led, above all in Germany, the country directly associated with the event, to increased reporting on the topic of European integration. However, such events can also radiate beyond the country in question: in May 1999 Kevin (2003) established increased reporting on the Common Agricultural Policy (CAP) in the eight states which she analysed - at a time when a dioxin scandal was smouldering in Belgium and a subsidy scandal was making headlines in Spain. As a third possibility, national events in a country can also overlie the EU reporting with the effect that it is hardly still visible even when an important EU event is taking place in parallel. For example, de Vreese (2003) comes to the conclusion that the European elections in June 1999 hardly featured in Netherlands reporting because at the same time a national government crisis was attracting the full attention of the media. 
3. Events outside the EU. Included here are events which happen outside the territory of the EU or lack any direct link to it. The material investigated in the meta-analysis includes only one example of this type of event, the Kosovo crisis at the beginning of 1999, which falls into the periods analysed by several studies. According to a number of studies (Grundmann et al., 2000; Kevin, 2003; de Vreese, 2003), it dominates the entire reporting and overlies EU events such as, for example, the European elections.

During interpretation of the results it is necessary to consider that when selecting news journalists generally orientate themselves strongly towards events, as is also postulated by the news value theory. Since, however, this is also the case with national events, very good comparisons can be made between the EU reporting and the reporting of EU events. Only when journalists consider an EU event to be important enough does it find its way into a newspaper or a programme and possibly displaces a national topic - although overall it is the national topics that are the main focus of reporting in the individual EU states.

The third research question can be answered relatively clearly on the basis of the available results: the degree of Europeanization of national public spheres - measured as an increase in the reporting of EU topics - rises steeply at the time of special occasions or events. These events may affect the entire EU or only individual states and then radiate out into other states. On the other hand, external European events such as the Kosovo crisis and national events can also hinder or prevent EU reporting.

\section{Discussion and conclusion}

Against the background of the widely discussed public and democracy deficit of the European Union, this contribution has attempted to search for signs of the existence or development of a European public sphere. It was assumed here that the European public sphere constitutes itself via the national public spheres, with the media public assuming central importance. To this end, 17 studies which investigate media reporting relating to the topic of the European public sphere via content analysis in a national comparison and were published between 1994 and 2003 have been viewed through the prism of meta-analysis.

Different dimensions or indicators of the Europeanization of national public spheres have been taken into consideration, these being a) a Europeanization through synchronization (operationalized by the reporting of EU topics), b) a vertical Europeanization (reporting of protagonists at the EU level) and c) a horizontal Europeanization (reporting of other EU states).

The meta-analysis shows that, overall, EU topics account for an extremely small share of reporting in the particular national media. Compared with national protagonists, the players at EU level also only feature in minor roles. It can therefore be stated that the publics of the EU states continue to exhibit a strong national orientation. Consequently, the national public spheres must be assessed as being only slightly europeanized overall. At best it is pos- 
sible to talk about the first signs of a European public sphere - by no means has "the" European public sphere emerged.

Different degrees of markedness in EU reporting between the media of the member states become apparent and, therefore, national differences in the markedness of Europeanization tendencies. The following findings number among the most striking results: by comparison, the media publics of the Netherlands, Denmark and Germany, too, are more europeanized. French, Spanish and Austrian media also devote themselves to Europe to a relatively high degree in contrast to the below average treatment in the Belgian, Italian and Irish media. The UK represents a special case: basically, British media report on EU topics and other EU states comparatively rarely. However, the reporting of EU topics and the naming of EU protagonists increase greatly when the euro or currency-policy aspects are involved. It must be assumed that this reporting then tends to be critical. Hardly any statements can be made about the other member states.

Statements about an increase or decrease in Europeanization tendencies over a period of several years or even decades are not possible either due to the inadequate state of empirical research on which this meta-analysis depends. The requisite analyses of time series comparing EU countries are not available.

Europeanization of the national public spheres increases on particular occasions. This applies in particular to big political EU events or events associated with the further development of European integration such as European elections, sessions of the European Council or the introduction of the Euro. As a rule, the extent of EU reporting increases in all of the states at the time of such events. This corresponds to patterns of journalistic selection according to which reporting is above all oriented towards events, this also representing the basis of the news value theory.

However, even in the case of EU-wide events it is not possible to talk about a complete synchronization of the debates since, here too, national differences emerge. On the one hand, national debates linked to the event can result in more intensive reporting of an EU topic as was the case, for example, with the 1985 EU summit in Milan when the Common Agricultural Policy was debated in Germany (Hodess 1998). The above-mentioned example of the UK reflects the special treatment of economic and currency-policy topics in this country. On the other hand, important events in the member states can also create a situation in which the national media hardly report an EU event at all. This happened, for example, in the Netherlands at the time of the 1999 European elections when the government crisis there displaced all other topics (de Vreese 2003). Both examples clearly indicate the strong national orientation of the media, something that can be explained via the news factors proximity, ethnocentricity or the degree to which one is personally affected.

With regard to the theoretical basis of this contribution or the meta-analysis it can be noted that, according to the current status of research, there are gaps in the model of a European public sphere as the result of the Europeanization of the national public spheres. To date 
no scale has been developed in international communication and media science by means of which the degree of Europeanization of national public spheres can be measured. As from what point is a public sphere (sufficiently) europeanized? And does "the" European public sphere emerge if all national public spheres are largely europeanized?

Empirical research relating to the European public sphere is an extremely demanding field requiring a high level of resources. In view of the considerable differences between the media systems and journalistic traditions, special care is needed with regard to the equivalence of the subjects of the analysis. Only one of the 17 studies evaluated here examines media from all $15 \mathrm{EU}$ states (Díaz Nosty 1997). On average, the researches are content to analyse newspapers or television news programmes from four states. In addition, most of the studies investigated here analyse only a short period of time around a particular (mostly EU-connected) event. It would be possible to answer the question about signs of a Europeanization of national public spheres considerably better using prolonged time series analyses which additionally include comparisons with routine periods and, as far as possible, examine all EU states. However, in view of the EU enlargement by ten states in 2004, such studies will now probably be more difficult to undertake than in the EU comprising 15 states. There is nevertheless such a research project, which examines the reporting in all 25 European Union states on the European elections in June 2004 by means of a content analysis (cf. Banducci/de Vreese 2004). ${ }^{12}$ Ideally, future media content analyses on the European public sphere should also pay more attention to the media set, avoiding the existing emphasis on newspapers with a relative elite readership.

The present study on the basis of a broad meta-analysis inevitably comes to the conclusion that the much-discussed deficit in terms of democracy and public in the European Union runs in parallel to a deficit in European media reporting, even if the first signs of a Europeanization of national public spheres are discernible. Again, it should be taken into account that, with the latest enlargement, the EU of now 25 member states consists of even more public spheres with different languages and reporting traditions than before. It will be a very demanding task for communication and media scientists to analyse the development of the deficit in media reporting in a new wave of empirical research.

By means of correspondingly extensive reporting the media of the EU member states should lay the foundation for a greater Europeanization of national public spheres which, in turn, can be the basis for the emergence of a common European public sphere. But of course not only the journalists are in charge. EU institutions and national governments should spare no effort to close the information gap beween Brussels policy and the everyday life of EU citizens.

This demand is particularly urgent against the background of a situation in which an essential part of the statutory rules and regulations affecting the citizens in the entire EU are to-

12 See also online: http://www.claesdevreese.com/research_european_elections_2004.html. 
day already decided on and passed in Brussels rather than in the nation-states. The present deficit in terms of public and democracy threatens to worsen still further if in future the EU comes closer together politically, something that is expressed, for example, in the European constitution: the more responsibilities the member states hand over to the European level, the more important Europe-wide debates on EU policy become.

\section{List of the studies examined in the meta-analysis}

Bange, Oliver (1999a) 'Wenig Kontinuität, wenig Hintergrund. Die EU-Berichterstattung europäischer Medien im Vergleich'. Medien Tenor Forschungsbericht 83, 15 April 1999: 38.

Bange, Oliver (1999b) 'Europas Medien ohne Konsens beim Thema Euro - unterschiedliche nationale Interessen gefährden die Stabilität der neuen Währung'. Medien Tenor Forschungsbericht 86, 15 July 1999: 36-7.

Díaz Nosty, Bernardo (1997) 'The European Union in the Press', pp. 19-125 in Foundation for the Development of the Social Function of Communication (Fundesco) \& Spanish Section of the Association of European Journalists (AEJ) (eds) The European Union in the media 1996. Madrid: Fundesco / AEJ Annual Report.

Díez Medrano, Juan (2001) 'Die Qualitätspresse und Europäische Integration'. Forschungsjournal Neue Soziale Bewegungen 15: 30-41.

Grundmann, Reiner, Dennis Smith and Sue Wright (2000) 'National elites and transnational discourses and the Balkan war. A comparison between the French, German and British establishment press'. European Journal of Communication 15: 299-320.

Hackenbroch, Rolf (2000) 'Wer weist Europa den Weg? Eine Analyse der deutschen und britischen Berichterstattung über Europa vom 1.4. bis 15.7.2000'. Medien Tenor Forschungsbericht 99, 15 August 2000: 36-7.

Hodess, Robin B. (1998) 'News Coverage of European Politics: A Comparison of Change in Britain and Germany', pp. 449-72 in Mathias Jopp, Andreas Maurer and Heinrich Schneider (eds) Europapolitische Grundverständnisse im Wandel: Analysen und Konsequenzen für die politische Bildung. Bonn: Europa-Union Verlag.

Kevin, Deirdre (2003) Europe in the Media. A comparison of reporting, representation and rhetoric in national media systems in Europe. London: Erlbaum.

Law, Marianne, David Middleton and Jerry Palmer (2000) 'The Press Reporting of European Economic and Monetary Union in Four European Countries: A Comparative Analysis', pp. 88-100 in Barbara Baerns and Juliana Raupp (eds) Information und Kommunikation in Europa. Forschung und Praxis. Berlin: Vistas.

Leroy, Pascale and Karen Siune (1994) 'The Role of Television in European Elections: The Cases of Belgium and Denmark'. European Journal of Communication 9: 47-69.

Meckel, Miriam (1994) Fernsehen ohne Grenzen? Europas Fernsehen zwischen Integration und Segmentierung. Opladen: Westdeutscher Verlag.

Palmer, Jerry (1998) 'L'Union monétaire dans la presse de cinq pays européens: quelques comparaisons quantitatives', pp. 43-62 in Marc Lits, Jerry Palmer and Wolfgang Settekorn (eds) L'Euro mediatisé. La construction de la monnaie unique dans les médias européens. Louvain-la-Neuve (BE): Les dossiers de L'ORM/COMU, Université Catholique de Louvain-la-Neuve.

Sievert, Holger (1998) Europäischer Journalismus. Theorie und Empirie aktueller Medienkommunikation in der Europäischen Union. Wiesbaden: Westdeutscher Verlag.

Sturm, Daniel and Oliver Bange (2000) 'Großer Graben zwischen England und Europa. Für britische TV-Sender waren EU-Institutionen im vergangenen Jahr kein Thema'. Medien Tenor Forschungsbericht 98, 15 July 2000: 38.

Trenz, Hans-Jörg (2002) Zur Konstitution politischer Öffentlichkeit in der Europäischen Union. Zivilgesellschaftliche Subpolitik oder schaupolitische Inszenierung? Baden-Baden: Nomos.

de Vreese, Claes H. (2003) Framing Europe. Television news and European integration. Amsterdam: Aksant.

de Vreese, Claes H., Jochen Peter and Holli A. Semetko (2001) 'Framing politics at the launch of the Euro: A cross-national comparative study of frames in the news'. Political Communication 18(2):107-22. 


\section{References}

Anderson, Benedict (1983) Imagined Communities. London: Verso.

Baerns, Barbara and Juliana Raupp (2000) 'Defizite der Forschung und Öffentlichkeitsdefizite in Europa', pp. 3942 in Barbara Baerns and Juliana Raupp (eds) Information und Kommunikation in Europa. Forschung und Praxis. Berlin: Vistas.

Banducci, Susan and Claes de Vreese (2004) The impact of poor information flow on the EU elections 2004. Paper presented at the Media Tenor 'Agenda Setting Conference 2004' in Bonn/Germany, 24 September 2004.

Beiler, Markus (2000) Experimente und Vorläufer: Grenzüberschreitende europäische Fernsehprojekte. Unpublished Manuscript, Hanover University of Music and Drama, Department of Journalism and Communication Research.

Beetham, David and Christopher Lord (1998) Legitimacy and the European Union. London: Longman.

Brettschneider, Frank (2002) 'Die Medienwahl 2002: Themenmanagement und Berichterstattung'. Aus Politik und Zeitgeschichte 49-50: 36-47.

Brosius, Hans-Bernd and Friederike Koschel (2003) Methoden der empirischen Kommunikationsforschung. Eine Einführung. Wiesbaden: Westdeutscher Verlag.

Council of the European Communities (1989) Council Directive 89/552/EEC of 3 October 1989 on the coordination of certain provisions laid down by Law, Regulation or Administrative Action in Member States concerning the pursuit of television broadcasting activities, available at: http://europa.eu.int/smartapi/cgi/sga_doc? smartapi!celexapi!prod!CELEXnumdoc\&lg=EN\&numdoc=31989L0552\&model=guichett (accessed 19 October 2004).

Council of the European Communities (1997) Directive 97/36/EC of the European Parliament and of the Council of 30 June 1997 amending Council Directive 89/552/EEC on the coordination of certain provisions laid down by law, regulation or administrative action in Member States concerning the pursuit of television broadcasting activities, available at: http://europa.eu.int/smartapi/cgi/sga_doc?smartapi!celexapi!prod!CELEXnumdoc\&lg= EN\&numdoc=31997L0036\&model=guichett (accessed 19 October 2004).

Díez Medrano, Juan (2003) 'Qualitätspresse und Europäische Integration', pp. 191-212 in Ansgar Klein, Ruud Koopmans, Hans-Jörg Trenz, Ludger Klein, Christian Lahusen and Dieter Rucht (eds) Bürgerschaft, Öffentlichkeit und Demokratie in Europa. Opladen: Leske + Budrich.

Eichhorn, Wolfgang (1996) Agenda-Setting-Prozesse. Eine theoretische Analyse individueller und gesellschaftlicher Themenstrukturierung. München: Fischer.

European Commission (1995-7) Euromedia. European Union press and television analysis No 1-33. Brussels: European Commission, DG X.

European Commission (2000) Socrates 2000 Evaluation Study Summary. Brussels. Contract No 1999-0979/001001 SOC 335 BEV.

European Commission (2001) Eurobarometer 54: Europeans and Languages. Executive Summary. February 2001. Brussels, available at: http://europa.eu.int/comm/public_opinion (accessed 10 July 2004).

European Commission (2004) Eurobarometer 60. Autumn 2003. Brussels, available at: http://europa.eu.int/ comm/public_opinion (accessed 10 July 2004).

Früh, Werner (2001) Inhaltsanalyse. Theorie und Praxis. Konstanz: UVK Verlagsgesellschaft.

Galtung, Johan and Mari H. Ruge (1965) 'The Structure of Foreign News. The Presentation of the Congo, Cuba and Cyprus Crises in four Norwegian Newspapers'. Journal of Peace Research 2: 52-66.

Gerhards, Jürgen (1993) 'Westeuropäische Integration und die Schwierigkeiten der Entstehung einer europäischen Öffentlichkeit'. Zeitschrift für Soziologie 22(2): 96-110.

Gerhards, Jürgen (2000) 'Das Öffentlichkeitsdefizit der EU: Theoretische Überlegungen und empirische Befunde', pp. 46-60 in Barbara Baerns and Juliana Raupp (eds) Information und Kommunikation in Europa. Forschung und Praxis. Berlin: Vistas. 
Gerhards, Jürgen (2002) 'Das Öffentlichkeitsdefizit der EU im Horizont normativer Öffentlichkeitstheorien', pp. 135-58 in Hartmut Kaelble, Martin Kirsch and Alexander Schmidt-Gernig (eds) Transnationale Öffentlichkeiten und Identitäten im 20. Jahrhundert. Frankfurt (Main): Campus.

Giering, Claus (2001) 'Die institutionellen Reformen von Nizza - Anforderungen, Ergebnisse, Konsequenzen', pp. 51-144 in Werner Weidenfeld (ed) Nizza in der Analyse. Strategien für Europa. Gütersloh: Bertelsmann Foundation Publishers.

Glass, Gene V., Barry McGaw and Mary Lee Smith (1981) Meta-analysis in social research. Beverly Hills: Sage.

Göler, Daniel and Silke Stammer (2004) 'Wie europäisch waren die Europawahlen 2004. Ein Vergleich der Medienberichterstattung in Deutschland und Frankreich'. Dokumente. Zeitschrift für den deutsch-französischen Dialog 60(4): 49-56.

Grimm, Dieter (1995) Braucht Europa eine Verfassung? München: Carl Friedrich von Siemens Stiftung.

Hagen, Lutz M. (ed) (2004) Europäische Union und mediale Öffentlichkeit. Theoretische Perspektiven und empirische Befunde zur Rolle der Medien im europäischen Einigungsprozess. Köln: Herbert von Halem.

Hasebrink, Uwe (1995) 'Trennende Gemeinsamkeit. Europäische Öffentlichkeit scheitert an nationalen Medienmentalitäten'. Agenda 21(6): 16-8.

Hrbek, Rudolf (1998) ‘Europäische Union', pp. 142-50 in Dieter Nohlen (ed) Wörterbuch Staat und Politik. Bonn: Bundeszentrale für politische Bildung.

Hunter, John E. and Frank L. Schmidt (1990) Methods of Meta-Analysis. Correcting Error and Bias in Research Findings. Newbury Park: Sage.

Imhof, Kurt (2003) 'Öffentlichkeitstheorien', pp. 193-209 in Günter Bentele, Hans-Bernd Brosius and Otfried Jarren (eds) Öffentliche Kommunikation. Handbuch Kommunikations- und Medienwissenschaft. Wiesbaden: Westdeutscher Verlag.

Kantner, Cathleen (2003) 'Öffentliche politische Kommunikation in der EU. Eine hermeneutisch-pragmatistische Perspektive', pp. 213-29 in Ansgar Klein, Ruud Koopmans, Hans-Jörg Trenz, Ludger Klein, Christian Lahusen and Dieter Rucht (eds) Bürgerschaft, Öffentlichkeit und Demokratie in Europa. Opladen: Leske + Budrich.

Kantner, Cathleen (2002) Transnationale Öffentlichkeit und die Demokratiefähigkeit der Europäischen Union, PhD dissertation, Berlin, Humboldt-University.

Kevin, Deirdre and Philip Schlesinger (2000) 'Can the European Union become a sphere of publics?', pp. 206-29 in Erik Oddvar Eriksen and John Erik Fossum (eds) Democracy in the European Union: Integration through deliberation? London: Routledge.

Kielmansegg, Peter Graf (1994) 'Läßt sich die Europäische Gemeinschaft demokratisch verfassen?' Europäische Rundschau 22(2): 23-33.

Kielmansegg, Peter Graf (1996) 'Integration und Demokratie', pp. 47-71 in Markus Jachtenfuchs and Beate Kohler-Koch (eds) Europäische Integration. Opladen: Leske + Budrich.

Kleinsteuber, Hans J. and Torsten Rossmann (eds) (1994) Europa als Kommunikationsraum. Akteure, Strukturen, Konfliktpotentiale. Opladen: Leske + Budrich.

Koopmans, Ruud and Jessica Erbe (2003) Towards a European Public Sphere? Vertical and Horizontal Dimensions of Europeanised Political Communication. Discussion Paper SP IV 2003-403. Berlin: Wissenschaftszentrum Berlin für Sozialforschung.

Lünenborg, Margret (2000) 'Europa ohne Öffentlichkeit? Theorien und Befunde europäischer Journalismusforschung', pp. 391-416 in Martin Löffelholz (ed) Theorien des Journalismus. Ein diskursives Handbuch. Wiesbaden: Westdeutscher Verlag.

Machill, Marcel (ed) (1997) Journalistische Kultur. Rahmenbedingungen im internationalen Vergleich. Opladen: Westdeutscher Verlag.

Machill, Marcel (1998) 'Euronews: the first European news channel as a case study for media industry development in Europe and for spectra of transnational journalism research'. Media, Culture and Society 20: 427-50.

Majone, Giandomenico (1998) 'Europes democratic deficit: The question of standards'. European Law Journal 4(1): 5-28. 
Meckel, Miriam (1994) Fernsehen ohne Grenzen? Europas Fernsehen zwischen Integration und Segmentierung. Opladen: Westdeutscher Verlag.

Medien Tenor (2002) ‘Fernsehen vorn’. Medien Tenor Forschungsbericht 125, 15 October 2000-10-15: 8.

Merten, Klaus (1995) Inhaltsanalyse. Einführung in Theorie, Methode und Praxis. Opladen: Westdeutscher Verlag.

Meyer, Christoph O. (2000) 'Towards a European Public Sphere? Transnational Investigative Journalism and the European Commission's Resignation', pp. 107-27 in Barbara Baerns and Juliana Raupp (eds) Information und Kommunikation in Europa. Forschung und Praxis. Berlin: Vistas.

Meyer, Christoph O. (2002) Europäische Öffentlichkeit als Kontrollsphäre: Die Europäische Kommission, die Medien und politische Verantwortung. Berlin: Vistas.

Neidhardt, Friedhelm (1994) 'Öffentlichkeit, öffentliche Meinung, soziale Bewegungen', pp. 7-41 in Friedhelm Neidhardt (ed) Öffentlichkeit, öffentliche Meinung, soziale Bewegungen. Kölner Zeitschrift für Soziologie und Sozialpsychologie, Sonderheft. Opladen: Westdeutscher Verlag.

Peter, Jochen (2003) Why European TV news matters. A cross-nationally comparative analysis of TV news about the European Union and its effects, PhD dissertation, Amsterdam: University of Amsterdam.

Schenk, Michael (2002) Medienwirkungsforschung (2nd edition). Tübingen: Mohr (Siebeck).

Schlesinger, Philip (1995) Europeanisation and the media: National identity and the public sphere. Unpublished working paper Arena 7-1995.

Schulz, Winfried (1998) 'Wahlkampf unter Vielkanalbedingungen. Kampagnenmanagement, Informationsnutzung und Wählerverhalten'. Media Perspektiven 8: 378-91.

Schulz, Winfried (1997) Politische Kommunikation. Theoretische Ansätze und Ergebnisse empirischer Forschung. Opladen: Westdeutscher Verlag.

Schulz, Winfried (1990) Die Konstruktion von Realität in den Nachrichtenmedien. Analyse der aktuellen Berichterstattung (2nd edition). Freiburg: Alber.

Siebenhaar, Hans-Peter (1994) Europa als audiovisueller Raum. Ordnungspolitik des grenzüberschreitenden Fernsehens. Opladen: Leske + Budrich.

Sievert, Holger (1998) Europäischer Journalismus. Theorie und Empirie aktueller Medienkommunikation in der Europäischen Union. Wiesbaden: Westdeutscher Verlag.

Staab, Joachim Friedrich (1990) Nachrichtenwert-Theorie. Formale Struktur und empirischer Gehalt. Freiburg: Alber.

Tobler, Stefan (2001) Bedingungen und Formen transnationaler Öffentlichkeiten. Ein konflikttheoretisches Kommunikationsmodell zur Beurteilung internationaler Politikprozesse am Beispiel des Kommunikationsereignisses 'Schädlicher Steuerwettbewerb im EU- und OECD-Raum', master thesis, University of Zurich, Soziologischen Institut, Forschungsbereich Öffentlichkeit und Gesellschaft.

Trenz, Hans-Jörg (2002) Zur Konstitution politischer Öffentlichkeit in der Europäischen Union. Zivilgesellschaftliche Subpolitik oder schaupolitische Inszenierung? Baden-Baden: Nomos.

van de Steeg, Marianne (2000) 'An analysis of the Dutch and Spanish newspaper debates on EU enlargement with Central and Eastern European countries. Suggestions for a transnational public sphere', pp. 61-87 in Barbara Baerns and Juliana Raupp (eds) Information und Kommunikation in Europa. Forschung und Praxis. Berlin: Vistas.

van de Steeg, Marianne (2003) 'Bedingungen für die Entstehung von Öffentlichkeit in der EU', pp. 169-90 in Ansgar Klein, Ruud Koopmans, Hans-Jörg Trenz, Ludger Klein, Christian Lahusen and Dieter Rucht (eds) Bürgerschaft, Öffentlichkeit und Demokratie in Europa. Opladen: Leske + Budrich.

Venturelli, Shalini S. (1993) 'The Imagined Transnational Public Sphere in the European Community's Broadcast Philosophy: Implications for Democracy'. European Journal of Communication 8: 491-518.

Weber, Eugen (1983) Peasants into Frenchmen. Berkeley: University of California Press. 
Weidenfeld, Werner (2001) 'Zwischen Anspruch und Wirklichkeit: die europäische Integration nach Nizza', pp. 19-49 in Werner Weidenfeld (ed) Nizza in der Analyse. Strategien für Europa. Gütersloh: Bertelsmann Foundation Publishers.

Wiesner, Volkert (1990) 'Fernsehen, Kultur und kulturelle Identität in Europa - ein Interpretationsversuch', pp. 157-79 in Hans J. Kleinsteuber, Volkert Wiesner and Peter Wilke (eds) EG-Medienpolitik. Fernsehen in Europa zwischen Kultur und Kommerz. Berlin: Vistas.

Wirth, Werner and Steffen Kolb (2003) ‘Äquivalenz als Problem: Forschungsstrategien und Designs der komparativen Kommunikationswissenschaft', pp. 104-31 in Frank Esser and Barbara Pfetsch (eds) Politische Kommunikation im internationalen Vergleich. Grundlagen, Anwendungen, Perspektiven. Wiesbaden: Westdeutscher Verlag.

Paper submitted for the CONNEX workshop „A European Public Sphere: How much of it do we have and how much do we need?", Amsterdam, December 9-10, 2005

\section{Contact}

Prof. Dr. Marcel Machill, MPA (Harvard)

University of Leipzig

Institute of Communication and Media Science

Chair of Journalism and International Media Systems

Burgstr. 21, D-04109 Leipzig/Germany

Phone: +49-341-97-35758 (Direct Line)

Phone: +49-341-97-35750 (Assistant)

Fax: +49-341-97-39330

Email: machill@uni-leipzig.de

\section{Markus Beiler, Dipl.-Media Scientist}

University of Leipzig

Institute of Communication and Media Science

Chair of Journalism and International Media Systems

Burgstr. 21, D-04109 Leipzig/Germany

Phone: +49-341-97-35781

Fax: +49-341-97-35799

Email: beiler@uni-leipzig.de

\section{Corinna Fischer, Dipl.-Journalist}

Am Mittelfelde 85a, D-30519 Hannover/Germany

Phone/Fax: +49-175-5218516

Email: corinna.eime@gmx.de 